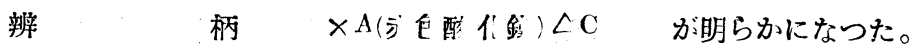

酸化ク口-ム $\triangle \mathrm{C}$

試製赤口黄鈶

3. 中性顏料

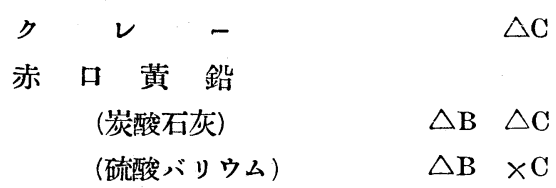

4. 詹蝕促進性顏料。

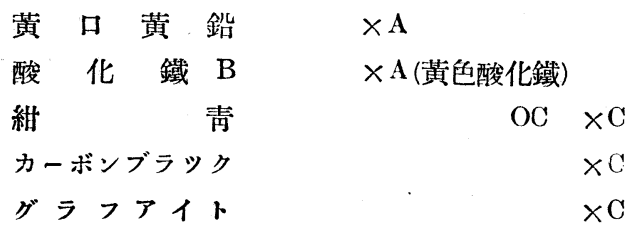

佔、上表に於いて、材方に記號を以て示したのは、文 獻に見えたる、他の測定者の實崄結果でめる。

記號の說明。

（抑錆作用むるもの。

$\triangle$ 中性、若しくは作用不明暸のもの。

$\times$ 抑錆作用なきもの。

A 堀田氏测定

B K. G. Lewis \& U. R. Evans の實驗。

C Thompson の實驗。

上表より、顏料の抑錆作用は、2-3 の例外を除き、試 料及び實驗者を異にしてる、大體平行した結果を示寸事
總括

1. 著者は諸種顏料の抑錆作用を檢した。

2、著者が試製した新顏料 3 種は、特に優れた抑鐠作 用を呈した。

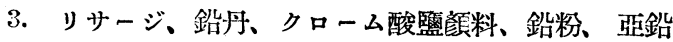
末、アルミニューム粉末等も、抑錆作用は優秀であつた。

4. 酸化鐵は、其の水溶性成分の多少によつて、著し く抑錆作用を異にした。

5. クローム酸鉛も亦、其の製法により、組成により、 著しく抑錆作用に差がある。

6. カーボンブラック、グラフアイト、紺青等は、著 しく鐵片の應蝕を促進した。

\section{文獻}

1) Proc. A. S. T. M. 7,493 (1907)

H. G. Gardner:-Phys. \& Chem. Exam. of Paint, Varn., Lacq. \& Colors P. 385.

2) Proc. A. S.T. M. 15, 220 (1915)

H. A. Gardner:-Phys. \& Chem. Exam. of Paint, Varn., Lacq. \& Colors P. 384.

3) J. Soc. Chem. Ind. 58, 25-33 (1934)

4) Farb. Ztg. 38, 1609, 1633, 1658 (1933)

5) Farb. Ztg. 40, 789, 811 (1935)

8\% 塗工の鬼斗 No. 411. P. 4\%. (1937)

\title{
Short Reports on Paints
}

府立東京商工獎鉭館工業試驗部 岩 井 信 次

\section{1. ローラーの練磨回數と粗粒子分との 關係に就て}

顏料、體貿と展色劑との練眰作業に於て、ローラーが 最も多く伐用される。普通常識的にはローラーに通す包 數を增す程製茧が優秀であることは誰しも認めることで ある、然らば何迅通せば最も良いかといふことに的確な る沃定はあまり知られない。著者は之を確めるために實 驗を試みた。實驗に使用せる材料の組成は次の如くでせ る。

$\left.\begin{array}{ll}\text { 亞鉛華 } & 85 \\ \text { 煮亞麻仁油 } & 15\end{array}\right\}$

上記の混合物を容器中にて混じ、ローラーにかけた。 各何のペーストは鐵道省塗料規格により試驗し、325 番 節上の殘渣を重量百分比にして示した。ローラーの締め
具合は之を數値的に示す方法なきため、操作上適當なる 程度に一定し扣きて、回數を重ねたり。ローラー回數 1 四のものは未だ顏料と油との練磒不完全なるものあるに より、第2四目より數值を取る。實驗の結果は次の通り である。ローラー（1）澢永く使用しや〉表面磨粍し たもの、(2)は新品にして、兩者いうれもチルド鋼製なり。

ローラー（1）による實驗結果

$\begin{array}{cc}\text { 包數 } & \text { 粗粒子分 }(\%) \\ 2 & 3.8 \\ 3 & 0.98 \\ 4 & 0.67 \\ 5 & 0.51 \\ 6 & 0.52 \\ 7 & 0.51 \\ 8 & 0.50\end{array}$


9

10

ローラー (2) による實驗結果
包數

2

3

4

5

6

7

8

9

10
0.51

0.52

粗粒子分 $(\%)$

0.61

0.21

c.21

0.21

c.22

0.50

0.18

0.22

0.20

第 1 圖 ローラー（片 による實驗結果

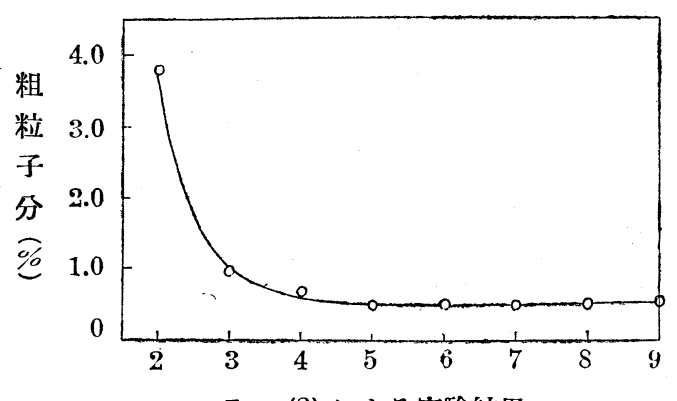

ローラー (2) による實驗結果

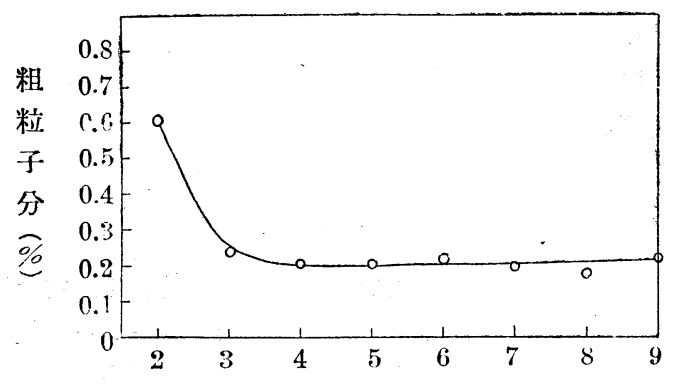

練 䁌 可 數

以上の數值を回示すれば第 1 圖の如くである。之によ りて明かなる如く、いづれも練磨包數 4 包乃至 5 包の 附近より粗粒子分は略々終極值をとり、それ以上回數を 増加するも粗粒子分の減少することはない。この終極值 は使用せる顏料、油及びローラーの表面の新舊に大いに

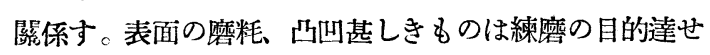
ず。即ちローラー (1) に於ては $0.50 \% に$ 於ては $0.20 \% に$ 至ることより明暸である。實際操業者 の言として、この塗料はローラー何可通したと稱してそ の製品の優秀性を包數の多きを以て䚷らんとする倾向む

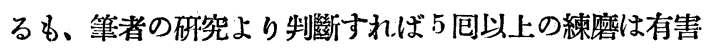
無益であつて、たよ゙徒らに動力を損し、機械部分の損傷 を招き、練碞ぺースト中に揮發分ある時は蒸發損失を墳 加し、又蒸發損失なき場合に於ても製品中に不純分を混 へ、純白を要する製品には污濁を交へるのみである。

\section{2.スパーワニスの耐水性}

スパーワニスが耐水性に於て、最もすぐれてるること は衆知の事舫であるが、然し製造條件によつてもその耐 水性に非常なる影響のあることはあまり制つてるない。 著者は之を確める積りで、天然樹脂について次の如き基 礎配合の本に少しく調べて見た。

\section{基礎配合}

$\begin{array}{lr}\text { ロヂン }(\mathrm{W} W) & 100 \\ \text { 支那桐油 } & 250 \\ \text { グリセリン } & 20 \\ \text { リサーヂ } & 2 \\ \text { ミネラルターペン } & 380 \\ \text { リノレン酸滿俺 } & 1 \\ \text { リレレン酸コバルト } & 0.5\end{array}$

但し支那桐油は沃素價 151 , 酸價 4.4, 膠化時間 7 分, 比重 $0.941\left(15^{\circ} \mathrm{C}\right)$ である。

製造條件を示す加熱曲線は第 2 圖の如くである。

第 2 圖 スパーワニスの加熱曲線

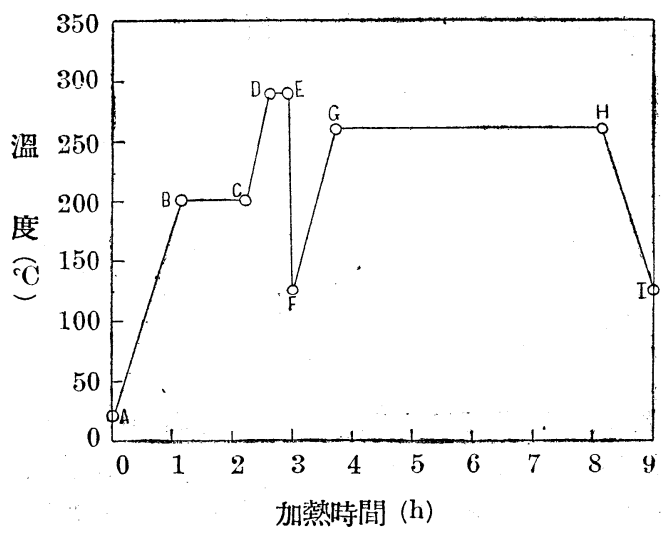

第2圖に於て、A-B 工程に於て、ロヂンと支邦桐油の 1 部とを融合し、Bに至るやグリセリン及リサーヂを除 々に加へて C に至りて完了するや、溫度を $28{ }^{\circ} \mathrm{C}$ まて 上昇し、D-E に沿ふて、約一定時間溫度を保ちて、ロヂ ンのグリセリンによるエステル化反應を進め、Eに至る や、殘餘の支那桐油全部を添加し、再び溫度を上昇し、 $260^{\circ} \mathrm{C}$ に數時間保つ。つ、でゲル化の直前に至りて反應 を中止し、冷却して溶劑及乾燥牒を加ふ。この操作に於 
て最も重要なるは DE のエステル化反應と $\mathrm{GH}$ の縮合 反應である。兩者の反應が適當に行はれない時には良好 なるワニスを製造することは不可能である。操作が適當 でない時には製造せられたるスパーワニスは顏料と練る 時固ることがある。適當なる條件の本に製造されたる時 は製品の酸價は非常に減少する。上記の配合の本に製造 せる 5 種のスパーワニスにつきその乾燥性、耐水性、酸 價を調べた結果次の數値を得た。

番 號酸價 乾燥時間 耐水性

$\begin{array}{rrrrrr}\text { スパーワニス } & 1 & 4.40 & 75 \text { 分 } & 20 \text { 日に至る } \\ \text { スパーワニス } & 2 & 5.72 & 120 \text { 分 } & 13 \text { 日 } \\ \text { スパーワニス } & 3 & 11.0 & 175 \text { 分 } & 9 \text { 日 } \\ \text { スパーワニス } & 4 & 16.5 & 300 \text { 分 } & 8 \text { 日 } \\ \text { スパーワ } & 5 & 18.4 & 350 \text { 分 } & 7 \text { 日 }\end{array}$

乾燥時間は溫度 $32.5^{\circ} \mathrm{C}$ に於ける指觸乾燥時間なり。 耐水性試驗は透明硝子板に試料を㙦附し、3 日閒乾燥せ るものを水慒中に斜に浸漬し、㳊膜に乳白化現晉を認む る迄の日數を示す。第 3 圖により明かなる如く、酸價 と乾燥時間とは㨁線的比例關係を有し、酸傮の低きもの 最も乾燥時間小なり。耐水性は酸價の減少と共に急激に

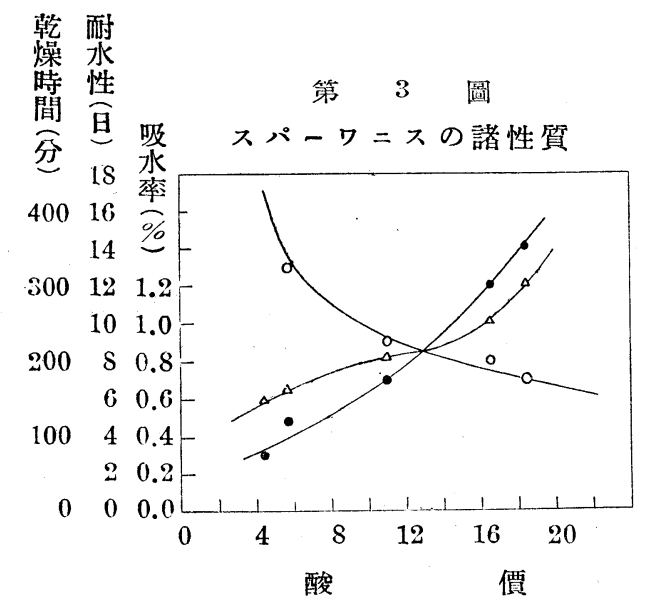

乾燥時間 增加す。之等ワニスと亞鉛華 耐水性 とを練るにスパーワニス (3) 吸水率 及び (4) は放置後粘る倾向め り。スパーワニス (1) 及び (2) 等にはこの現象なし。 又之等の耐水性と關係もる吸水率測定の結果次の値を得 たり。

\begin{tabular}{|c|c|c|}
\hline 試料番號 & & 吸水率 $(\%)$ \\
\hline スパーワース & 1 & 0.59 \\
\hline スパーワニス & 2 & 0.65 \\
\hline スパーワ & 3 & 0.82 \\
\hline スパーワニス & 4 & 1.0 \\
\hline
\end{tabular}

$$
\text { スパーワニス } 501.2
$$

但し、吸水率は 3 日間乾燥せるものにつき 24 時間蒸 溜水中に浸漬せるものにつきて行ひたるものなり。以上 の結果を要約すればロヂンー桐油系スパーワニスの性質 は製品の酸價により非常なる影響をもち酸偪の低きもの 程塗料としての性質優秀である。よつて製造に際して は、酸價の低下を計るべく操作することが最も重要であ ると考へられる。

\section{3. 乾燥劑の比較試驗}

塗料の乾燥放として最も膺く用ひられるものは主とし て、コバルト、滿俺、鉛等の脂肪酸監、樹脂酸監等であ るが、それ以外の金屬石監の乾燥能力を調べることも興 味あることと思ひ、實驗を行つた。普通には常溫附近の 溫度に於ける乾燥時間が最も重要なる意味をるつが、そ れ以上の高溫度に於ける乾燥能力及乾燥時間等の變化を

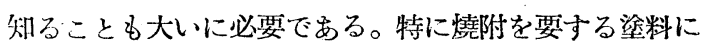
就ては、之が大きい關係をもつものである。

賸驗の方法は次の如くである。即ち亞麻仁油 $100 \mathrm{~g}$, 苛 性曹達 $14 \mathrm{~g}$ の割合にて崄化を行ひ.つぎに水溶性金屬盤 溶液を加一て充分沈澱せしめ、之を $80^{\circ}-85^{\circ} \mathrm{C}$ の溫水 にて數印洗滥し、全く過剩の金屬イオン及その他の水溶 性物貿の消失するまで行ひ、最後に之を可及的に水を除 去し、㰓化カルシウム入デシァーター中に乾燥した。こ の乾燥物を生严麻仁油 $100 \mathrm{~g}$ と混和し、除々に加熱して 充分溶解す。之を乾燥劑とする。實驗に際しては之の一 定量を取り、燃燒して、その灰分を定量して金屬含有量 を湘定しょく。瑹燥劑はその製造方法により製品の性質 に大いに影響を與へるのでなるべく低溫度を用ひ、同樣 なる條件にて製造した。この乾燥劑の一定量を煮亞麻仁 油に添加し、その金屬含有量を $0.2 \% な る$ 如くした。

澺亞麻仁油の製浩法は次の如くである。精製亞麻仁油 を $200^{\circ} \mathrm{C}$ まで加熱し、ついで加熱を中止し、空氣を除々 に約 3 時間吹込む、 3 時間後の溫度は $120^{\circ} \mathrm{C}$ である。か くして製造せる著亞麻仁油は殆ど無色に近く、之を試料 として用ひた。

优用せる金屬鹽類は次の 13 種である。即ち硫酸アル ミニウム、監化バリウム、硝酸蒼鋁、鹽化カルシウム、觜

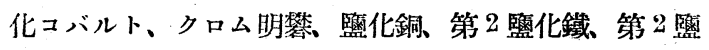
化水銀、監化マグネシウム、硫酸滿俺、醋酸鉛、硫酸亞 鉛でむる。上記監類中加水分澥し易きものは酸性溶液と して优腪寸。

實驗溫度は $30^{\circ} \mathrm{C}$ 艾び $100^{\circ} \mathrm{C}$ である。濕度は本均 75 \%である。 
清潔なる确子板上に試料を流展し、垂值に扣き實驗溫 度に保つ。 $100^{\circ} \mathrm{C}$ に於ては 5 分每に、 $30^{\circ} \mathrm{C}$ の場合には 10 分乃至 20 分每に、乾燥逮きものは预定の乾燥時間前 2 時間乃至 3 時間前に於て 20 分乃至 30 分每に、硝子 板の緣より $3 \mathrm{~cm}$ 位離れたる所を指端にて輕く觸れても 粘着性を感ぜず、輕く擦つても疵を生じない時を以て乾 燥時間とする。正確を期するため同一の實驗を 3 包行 ひ、その平均值を取る。實驗の結果は次の如くである。

(3 间の平均值)

含有金屬名
$\mathrm{Co}$
$\mathrm{Mn}$
$\mathrm{Pb}$
$\mathrm{Fe}$
$\mathrm{Cu}$
$\mathrm{Cr}$
$\mathrm{Al}$
$\mathrm{Zn}$
$\mathrm{Bi}$
$\mathrm{Mg}$
$\mathrm{Ca}$
$\mathrm{Ba}$
$\mathrm{Hg}$

金屬不含

以上の結果を通覽するに次の如く認められる。コバル 小は $30^{\circ} \mathrm{C}, 100^{\circ} \mathrm{C}$ のいづれに於ても乾燥牒として第一位 にあり、满俺之に次ぐ。鉛は $30^{\circ} \mathrm{C} に$ 於てはや〉鐵に劣 り、 $100^{\circ} \mathrm{C}$ に於ては同じ、即ち鐵は乾燥劑として使用さ れることが少いが鉛と同樣なる乾燥力ありと考へられ る。たが惜むらくは試料油に着色させることが缺點であ る。銅、クロムは $30^{\circ} \mathrm{C}$ に於ては有力なる乾燥力無けれ ども $106^{\circ} \mathrm{C}$ に於ては鉛と相比眉寸る性能あるを認め得 る。

亞鉆、マグネシウム、カルシウム、バリウム、支び水 銀は $30^{\circ} \mathrm{C}$ に於ては大體に於て金屬を全く含有せざる場 合に比すればや小乾燥力を有するも、アルミニウム、蒼 錩等は全くこの能力無し。 $100^{\circ} \mathrm{C} に$ 於てはアルミニウ ム、㰳鉛、蒼鉛、マグネシウム、カルシウム、バリウム、 及び水銀等はいづれも金屬なき場合と同樣である。即ち ある溫度に於て乾燥力優れたるもの必ずしも、他の溫度 に於て優秀なりと斷定するを得ず。又逆に低溫に於て乾 燥力全く無きものといいども高溫に於ては優れたる乾燥 力を有する銅、クロム等の如きものも安り、一樣に論ず ることはできない。

\section{セラツク及びセラツクワニスの蠟分の定量法に就いて}

\section{I. 緒言}

セラック伎びセラック・ワニスの品質檢定に於いて、 褱分を分離、定量する事は重要な事項であるにも關らず、 現在蠟分の定量法に就いては一完の規格がなく、色々の 方法が呈示されて居て、實際に工業分析を行ふに際して 何れの方法を探孔ば好都合でるるか、その探否、選擇に 迷ふのである。此の故に著者は是等の万法に就いて實驗 を試み、其の結果を比較して、當事者の參考に供する所 以である。

\section{II. 文 献}

K. Dieterich に依ればセラックが純粹な場合には是を 石油ペンヂン (b.p $\left.60^{\circ} \mathrm{C}\right)$ にて抽出すれば、蠟分は石油ペ ンヂン中に全部溶解してくるから分離、定量する事が出

\section{䅇知工業試驗所乾忠孝}

來るとされて居る。 Langmuir はゼックク稀溥な炭酸 ソーダ水溶液と共に溫めて、溶解し、冷却して、濾過す る事により蟉分をセラック・レヂンと分離し、殘㴡をソ クスレー装置を用ひ、石油ベンヂン $\left(\right.$ b.P. $\left.60^{\circ} \mathrm{C}\right)$ にて抽出 すれは䗵分は全部石油ベンヂンに溶解してくるから、不 油ベンヂンを除去して科量すれば定量し得ると述べて唇 る、MCiheny はセラックをアルコールに溶解し、是に 過剩のアルカリ及び石油エーテルを加一、分液漏斗に移 し少量の水を注加し、石油ェーテル層を分別し、修アル コール部分より石油エーテルを以て再び抽出して、不油 エーテル部分を一緒にし、それより石油エーテルを驅悇 して科量し、繒分を定量する事を述べて 居る。 O. M. Olsen はセンックをアルコールに溶解し、不溶解性殘渣 をソクスレー裝置を用ひてクロロホルムにて抽出して、

1) K. Dieterich : Analysis of Resins, Balsams \& Gum-resins 297 (1920)

2) Livache \& Mcintosh : The Manufacture of Varnishes and Kindred industries.

3) 2)に同じ Vol III. 304-312 (1911)

4) O. M. Olsen : Ind. Eng. chem., Anal, Ed. 4, 47 (1932)

Vol III. 308-310 (1911) 